Journal of Southeast Asian

Volume 10

2015

\title{
Hmong Culture Club as a Place of Belonging: The Cultivation of Hmong Students' Cultural and Political Identities
}

Bic Ngo

University of Minnesota - Twin Cities, bcngo@umn.edu

Forty and Forward: Research on the New Second Generation of Southeast Asian American

Students

Vichet Chhuon

University of Minnesota

anthony lising antonio

Stanford University

Follow this and additional works at: https://docs.lib.purdue.edu/jsaaea

\section{Recommended Citation}

Ngo, Bic (2015) "Hmong Culture Club as a Place of Belonging: The Cultivation of Hmong Students' Cultural and Political Identities," Journal of Southeast Asian American Education and Advancement: Vol. 10 : Iss. 2, Article 2.

DOI: $10.7771 / 2153-8999.1130$

Available at: https://docs.lib.purdue.edu/jsaaea/vol10/iss2/2

This document has been made available through Purdue e-Pubs, a service of the Purdue University Libraries. Please contact epubs@purdue.edu for additional information.

This is an Open Access journal. This means that it uses a funding model that does not charge readers or their institutions for access. Readers may freely read, download, copy, distribute, print, search, or link to the full texts of articles. This journal is covered under the CC BY-NC-ND license. 


\title{
JSAAEA Journal of Southeast Asian American
Education and Advancement
}

Vol. 10 Iss. 2 Special Issue (2015)

WWw.JSAAEA.org

\section{Hmong Culture Club as a Place of Belonging: The Cultivation of Hmong Students' Cultural and Political Identities}

\author{
Bic Ngo, Ph.D. \\ University of Minnesota
}

\begin{abstract}
In this article, I draw on a year-long ethnographic study of an after school "Hmong Culture Club" to illuminate the ways in which it provides students with a place of belonging. I reveal the ways in which Hmong students in this setting take up ideologies of multiculturalism in response to a sense of the "loss" of Hmong culture. I explore the ways in which the Hmong Club provided Hmong students with a place to belong that simultaneously cultivated their cultural and political identities. Ultimately, I suggest that school extracurricular cultural clubs may provide insights to subtractive schooling (Valenzuela, 1999) as well as ways forward for understanding the importance of spaces for (ethnic, racial) group identity. This article will advance knowledge of the spaces of co-curricular ethnic student clubs that are the contexts for the changing dynamics of immigrant culture and identity.
\end{abstract}

Keywords: Hmong, immigrant, culture, identity, hybridity, place

\section{Introduction}

With a yellow flyer in hand, Paul Vue tells the members about the Hmong Culture Day events at a local state college, which includes a talent show and a dance. While he explains in Engish, Tom Lor interprets in Hmong to the two ELL girls. In his role as interpreter Tom Lor has trouble with the words "student," "talent show" and "dancing" and seeks help from Mr. Moua and Ms. Khang. The other Club members laugh at his trouble, and laugh considerably more when Mr. Moua translates "dancing” into Hmong as "shake body." Tom Lor shrugs, laughs, and says, "We speak Hmonglish here.” (FN, 11/8/06, Hmong Club)

Hmong American immigrant youth are navigating multiple cultural repertoires and creating "Hmonglish" identities that draw on multiple discourses of being in the world. They are

\footnotetext{
(C)

SORERIISHISRESERNEDReaders are free to copy, display, and distribute this article, as long as the work is attributed to the author(s) and the Journal of Southeast Asian American Education \& Advancement, it is distributed for non-commercial purposes only, and no alteration or transformation is made in the work. More details of this Creative Commons license are available at http://creativecommons.org/licenses/by-nc-nd/3.0/. All other uses must be approved by the author(s) or JSAAEA.

Journal of Southeast Asian American Education \& Advancement, Vol. 10 Iss. 2 Special Issue (2015) ISSN: 2153-8999
} 
carving out spaces to participate in and create identities that are at once local, global and transnational (Maira \& Soep, 2005). And yet, the complexities and incongruities (Maira, 2002; Ngo, 2010a; Yon, 2000) of their lives are regularly reduced to narratives that spotlight delinquent behavior, school failure, beating-the-odds success or intergenerational conflict. More often than not, the experiences of immigrant youth are framed as either problems of "tradition" or "cultural clash" (Ngo, 2008). The former storyline points to problems arising out of an attachment to traditional practices of a stable, "originary" culture (e.g., Louwaigie \& Browning, 2005); while the latter emphasizes the collision between "traditional" values of immigrants and that of a "modern" Western society (e.g., Feagans, 2006).

This article grows out of a compelling need to explore the everyday lives of immigrant youth in ways that highlight the interconnections between space, place, and the discursive construction of cultural identity. Geographers and anthropologists interested in space and identity suggest that youth are significantly influencing and influenced by the spaces they occupy. In the "inscribed spaces" (Low \& Lawrence-Zuniga, 2003, p. 13) of home, school and community, youth "write" in their presence, as they engage in relationships and attach meaning to space. In doing so, they transform "space" into "place" (Entrikin, 1991).

The purpose of this article is to examine the activities of a high school's "Hmong Culture Club" (HCC) to illuminate the ways in which it is a "home" (Hall, 1995; see also hooks, 1990) for Hmong American high school students. It is guided by two interrelated questions: (1) What are the concerns about the social and cultural marginalization of Hmong American students? and (2) How does a Hmong Culture Club provide students with a space of belonging? In this article, I reveal the ways in which Hmong students take up ideologies of multiculturalism and ethnic authenticity in response to a sense of the loss of Hmong culture. I explore the ways in which Hmong Club provided Hmong students with a place to belong that simultaneously affirmed their Hmong American identities. Ultimately, I suggest that school extracurricular cultural clubs may provide insights to subtractive schooling (Valenzuela, 1999) as well as ways forward for understanding the importance of (ethnic, racial) group identity. This article will advance knowledge of the spaces of co-curricular ethnic student clubs that are the contexts for the changing dynamics of immigrant culture and identity.

\section{Theoretical Background}

In this article, I draw on social and cultural geography to examine the roles of space and place in the construction of cultural identities (Low \& Lawrence-Zuniga, 2003). Cultural geographers (e.g., Anderson, et al., 2002; Massey \& Jess, 1995) analyze space, place, and identity as a set of interactions in order to understand cultural change within spatial context. They suggest that as individuals with particular racial, ethnic, gender and class identities, we imbue spaces with specific cultural meanings. "Space as location" and "space as place" are distinguished by cultural meanings produced by human actions (Entrikin, 1991; Massey \& Jess, 1995). People transform "space" into "place" by making locales meaningful through relationships and experiences (Entrikin, 1991; Rose, 1995).

Entrikin (1991) suggests that "the significance of place is associated with the fact that as actors we are always situated in place and that the context of our actions contributes to our sense of identity" (p. 4). Importantly, our "situatedness" in place contributes to the social construction of our cultural identities. Entrikin maintains: "As agents in the world we are always 'in place,' much as we are always 'in culture.' For this reason our relations to place and culture become 
elements in the construction of our individual and collective identities" (p. 1). To highlight the relationship between place and culture, he further stresses that "[p]laces are significant not because of their inherent value, but rather because we assign values to them in relation to our projects" (p. 16). Spaces thus become meaningful to us through our commitments (i.e., projects), actions and interactions as individuals and as members of groups.

Rose (1995) suggests that the meanings individuals attach to place - "senses of place""are shaped in large part by the social, cultural and economic circumstances in which individuals find themselves....feelings about place are caught up in power relations which structure all our lives" (p. 89). The awareness of cultural difference between various groups may prompt some groups to mark that difference from other groups through claims of belonging to a particular place that simultaneously excludes the other groups.

In a similar vein, Hall (1995) finds that culture especially provides individuals with a sense of place much like that of a "home":

We think of our culture as a home - a place where we naturally belong, where we originally came from which first stamped us with our identity, to which we are powerfully bonded, as we are to our families, by ties that are inherited, obligatory and unquestioning. To be among those who share the same cultural identity makes us feel, culturally, at home. Culture gives us a powerful sense of belongingness, of security and familiarity (p. 182, emphasis in original).

For minoritized ethnic and racial groups, the construction of cultural spaces (and boundaries) for within-group members provides groups with important sites for sanctuary and belonging. This strategy of keeping culture "closed" includes efforts "to hold fast to cultural traditions, to reaffirm those elements of the culture which maintain the links to one's past, [and] to keep the connection "pure'” (Hall, 1995, p. 200; see also, Gilroy, 1994).

As the following sections reveal, this lens for examining the interconnections between culture, space and place may provide insight for understanding the significance of a high school's Hmong Culture Club as a space for cultural belonging and political self-discovery.

\section{Research Background}

This article draws on data from a large ethnographic study on the role of culture and cultural change in the education of Hmong American high school students. The research took place at Dayton High School in Harriet City, an urban center in the Midwestern United States with the world's largest urban population of Hmong immigrants. The study also included fieldwork at Hmong community events and interviews with teachers and peers at the school, and Hmong parents and community leaders from the local community.

Dayton High School is one of seven high schools in the Harriet City Public Schools. During the 2006-2007 academic year in which this study took place, it had the second largest high school enrollment (by less than 15) at 2,107 students. The student population was comprised of 21\% African American, 2\% American Indian, 49\% Asian American, 10\%, Latino American, and 21\% White American. Hmong American students represented the largest ethnic group in the district (30\%) as well as the largest group at Dayton High $(46.4 \%)^{\mathrm{ii}}$. Fifty-one percent of the students in the school were English Language Learners ( $2^{\text {nd }}$ in district) and $77 \%$ received free or reduced lunch $\left(3^{\text {rd }}\right.$ in district $)$. 
Ethnographic research underscores deep immersion in the everyday lives of research participants to allow for nuance and depth of understanding (Fetterman, 1998). The Hmong students in my study either came to the U.S. when they were young (1.5 generation) or were born in the U.S. ( $2^{\text {nd }}$ generation). The Hmong adults included parents, policymakers and directors of Hmong mutual assistance organizations. This article focuses on my ethnographic research with Hmong high school students, teachers, parents and community leaders.

I conducted extensive fieldwork at the school four to five times a week (approximately 540 hours), which include attending classes and extracurricular activities such as club meetings, dances, and sports events. These observations resulted in fieldnotes (Emerson, Fretz, \& Shaw, 1998) that described the setting, activities and participants' behaviors and recounted conversations. I also recorded my thoughts and initial interpretations in a log with analytic notes. In addition, my fieldwork included the collection of artifacts and documents such as class handouts, assignments, announcements, school demographic data, and community newspapers.

I used the details and information that I gleaned from the participant observations to construct questions for the interviews. My interviews with students $(n=30)$ primarily asked them to share information and perspectives about their daily lives and experiences in the school and community. The interviews with Hmong parents $(n=5)$, Hmong community leaders $(n=9)$, teachers and staff $(n=17)$ aimed to elicit their perspectives about the education of Hmong American children and families. These interviews usually lasted an hour and often took place after school in the library, empty classrooms, or at community centers and offices. ${ }^{\text {iii }}$

Data analysis was guided by the constant comparative analysis of grounded theory procedures (Strauss \& Corbin, 1998). The iterative process helped me to triangulate patterns across participants and data sources and "ground" my findings in the data. The first two stages included open-coding for all possible themes from the data and axial coding that identified a smaller set of salient categories. The research goals and questions informed the selection of the smaller set of categories. Data was then re-read and re-coded with the selected categories. Relationships and inconsistencies among categories were identified and categories reorganized. Lastly, I identified a select set of major categories that were central to the study. This smaller set of ideas provided the major topics and themes for deeper analysis and for the writing of the article.

My research with Hmong immigrant youth and families is imbued with different dimensions of my identity (Denzin \& Lincoln, 2000). This includes my experiences as a 1.5generation refugee from Vietnam as well as an earlier life as an employee at a Hmong non-profit, social service agency. As a scholar of education, I seek to especially understand the ways in which schools advantage some groups over others, as well as the ways schools are sites of social and cultural transformation. While my research is partial (Britzman, 1995) and infused with my choices and interpretations (Fine, 1994), I endeavored to represent my participants in their own terms.

\section{"Returning to Roots" in the Community}

Hmong American immigrants in Harriet City created multiple spaces to serve the social and cultural needs of the Hmong community. Numerous charter schools, non-profit organizations and programs iv emphasized the importance of a "return" to Hmong culture. Hmong charter schools in the area sought to teach children about Hmong language, rituals, folklore and dance as an integrated element of the academic curriculum. These Hmong-specific schools offered curriculum that "integrates Hmong language and culture" or that is "enriched and informed by 
Hmong culture and language." In addition to charter schools, various Hmong mutual assistance organizations (cf., Zhou \& Kim, 2006) provided educational programs to families that focused on "traditional" Hmong cultural practices. Various mission statements declared aims such as: "empower Hmong families to acculturate to life in America . . . while retaining their cultural heritage and identity," "empower the Hmong to meet the many challenges of modern American life within a context that honors and preserves their traditions, values, and heritage," or "preserve Hmong culture and language through storytelling, gardening and the arts."

In their examination of the relationship between places and cultures, Massey and Jess (1995) ask, "[I]n the case of both place and of culture: which story of past and present will be told? (p. 232). This question implies a multiplicity of the stories about culture that are available for making sense of the past and present. For the Hmong American community in Harriet City, the answer to this question by and large reflected a "closed" (rather than an "open" or dynamic) notion of culture (Hall, 1995). Hmong immigrants told a story that "assumes that the further you get from your origins, the more you are separated from your "true culture"' (Hall, 1995, p. 207). In this version of identity, individuals with a shared (e.g., ethnic, racial, national) culture hold in common a "collective "one true self" of identity that is "stable, unchanging and continuous" (Hall, 1990, p. 223). This linear idea of culture privileges "tradition" as the vital link that connects individuals to their cultural identity.

In my interviews with Hmong community leaders, they emphasized the need to "return" to Hmong cultural roots. Their observations of the struggles of Hmong students and families underscored the theme of "a sense of loss of identity." Simultaneously, they hinted at an awareness of cultural imperialism in U.S. society. Consider the words of Kou Vang, a Hmong policymakerv:

My generation, we came here, we knew exactly where we were born, we knew exactly how we got here and we knew that we were poor. And we weren't ashamed of being poor because we didn't know any better. And we worked hard at it, to not be poor. But we had this, we were well grounded. We knew exactly who we were. We didn't question our identity. We could speak the language, understand our parents, where they're coming from, communicate well with them. But with someone who was born here, I think that's harder. They don't kind of know where they're from .... And so I think a sense of loss of identity goes into that. Some of them feel they don't know who they are, so they're trying to find out who they are. ... That with not knowing what your identity is, you're kind of lost. You don't feel like you belong with the Hmong community because maybe you don't speak Hmong anymore. Maybe your parents are doing weird stuff that you don't understand. But then at the same time you feel like you don't belong in the mainstream community either because you don't look like everyone else. So there's I think a sense of feeling lost for some of these young people (my emphasis).

According to Kou Vang, as a first-generation immigrant, he was "well grounded" in his cultural heritage and "didn't question [his] identity." However, for second-generation Hmong youth, their cultural identity is more ambiguous due to a sense that they do not "belong with the Hmong community" because of a lack of language and knowledge about why "parents are doing weird stuff" [rituals]. The community leader suggested that "loss of identity" among Hmong youth is not just about loss of cultural knowledge, but also about exclusionary practices by the mainstream community "because [they] don't look like everyone else." vi 
Pachee Vue, another policymaker, echoed Kou Vang's sentiments. As she put it: "Because kids want to fit into the mainstream, at the same time they are being picked on because kids are saying, "you can't fit into both worlds." To address the struggles of Hmong youth, Vue suggested helping Hmong youth "understand who they are":

And so our goal is to help our children understand who they are to the point where they are confident to say, "I am a Hmong American, and I'm proud to be a Hmong American, my Hmong-ness is as important as my American, my citizenship." And so that's where we are right now. We're offering bilingual classes, bilingual educational, we're learning oral, learning the Hmong language, the Hmong culture, the Hmong dances, the Hmong queej, the Hmong story cloth. We're bringing that back to the school, so not only the Hmong students are learning, but others are also learning and are understanding who the Hmong are. Because there's, once there's a gap of misunderstanding because we don't know who the Hmong are, we don't know why they're here, we don't have any history, there's nothing that's written in history books about the Hmong (my emphasis).

According to the policymaker, a "closed" notion of Hmong culture was important for the social and educational success of Hmong children. Classes that focused on Hmong language, dance, queej, among other traditions would help Hmong children with their identity struggles. She alludes to practices of "subtractive schooling" (Valenzuela, 1999) that exclude the knowledge and perspectives of Hmong ethnics from the school curriculum. Further, Vue's remark that schools needed to teach Hmong children that "my Hmong-ness is as important as my American, my citizenship" is noteworthy. While the policymaker used the term "Hmong-ness" to refer to Hmong identity, she did not correspondingly use "American-ness." Rather than acknowledging the "American" identity of youth, she shifted to "my citizenship" to convey Hmong youth's legal (as opposed to cultural) ties to the U.S.

Tuan's (1998) work with fourth and fifth generation Japanese and Chinese Americans highlights the salience of race for Hmong youth. She states that "[p]eople of Asian ancestry in this country are relegated to the margins based on race and on what I call an assumption of foreignness. That is, they continue to be seen as somehow more Asian (or Chinese or Japanese) rather than American" (p. 18, emphasis in original). In other words, U.S.-born Asian Americans such as second-generation Hmong youth are perceived to not be "American." The struggles of Hmong youth are thus not simply about a cultural loss, but with the racial politics of identity in U.S. schools and society (Lee, 2005). In other words, Hmong youth struggle to belong because they continue to be viewed as "foreigners."

Because notions of "home" and "homeland" have been important sites of freedom and resistance, the attachment of Hmong American immigrants to "closed" identities can be important for oppressed groups such as Hmong immigrants (Massey \& Jess, 1995, p. 233). Similar to the broader Hmong community, the Hmong Culture Club at Dayton High School took up discourses of a cultural "return." As the next two sections reveal, the outcome was incongruous-Even as Hmong students redeployed discourses of ethnic authenticity that reified Hmong culture and identity, the transformation of Hmong Club from "space" into "place" through their social relations provided them with a place of belonging and nurtured their identities as Hmong Americans. 


\section{Carving out Belonging}

In U.S. schools, multicultural education frequently manifests as a "month" or a "day," posters, display case exhibits, and co-curricular student groups with aims to "celebrate," "respect," "recognize," and "include" various ethnic and racial groups (Lugones \& Price, 1995; Ngo, 2010b). This multicultural education is often critiqued as "ornamental" (Lugones \& Price, 1995) or "boutique" (Fish, 1997) for the ways in which it teaches about cultural "diversity" by drawing on a "closed" notion of culture. Liberal multiculturalism is "banal" Thomas (2008) suggests, because it has become "rote" and without articulated purpose and contextualization (p. 286). Dayton High included all of the above multicultural programming, highlighted by a "Multicultural Festival" that featured a fashion show with ethnic music, dance, and clothing as well as themed student group booths that sold "ethnic food."

At Dayton High the Hmong Club took up this "banal" multiculturalism of a "closed" understanding of culture in the discursive constructions of the purpose of the Club:

Paul Vue looks a little like the hip-hop artist, Nelly, with a piece of thin, white athletic tape under his left eye, similar to the use of eye black by football players to reduce glare. The Vice President of the Club is dressed in jeans, an orange t-shirt and gray, hooded zip sweatshirt. In the absence of Blia, the President, he starts the meeting by casually saying "Hey, everybody!" and jumping to sit on the teacher's desk at the front of the room as members end their conversations. The other officers, Tom Lor and Pakou, smile at him from their seats at desks in the room. "So, who has a joke?" Several of the club members laugh. One student offers a joke about his mom using oil in cooking, which ends with the punch line of "Oy, oy, oy, oy!" from his mom.

As the members erupt into laughter, Blia walks briskly into the room and passes out a typed agenda. She positions herself at the podium at the front of the room and calls the meeting to order again with "Okay, listen up" in a stern, curt voice. She tells the members the meeting will cover the items on the agenda, and adds that they can "skip" item \#3, "review of last meeting" because she already received an update. Blia says, "I heard it was very loud and chaotic." All of the officers are convened at the front of the room, leaning against the white board and looking somber.

Mr. Moua, the Club's advisor, raises his hand and suggests, "You should ask students if there are other items that they want to add [to the agenda]." A Hmong female student sitting close to the door asks "What's the purpose of the Hmong Club?" In a serious voice, Blia responds, "The purpose of the Hmong Club is to establish a Hmong community at the school, to bring together Hmong and other students. Americans and Somalians [sic] can also join." Blia adds that the Club is also intended for students to "learn about your history." Mr. Moua stands up and tells students that it is a "support group" where students can learn about Hmong culture and Hmong language. He adds, "Every few weeks, I'll give a Hmong language lesson." (FN, 9/26/06, Hmong Club)

In this meeting a few weeks into the school year, figureheads Blia and Mr. Xiong, asserted a goal of "revival of ethnicity" (Hall, 1995, p. 200) for the Hmong Club where students could learn about their history, culture and language. Other club members shared in interviews 
that they saw the Club functioning to "help unite Hmong people" and "bring Hmong people out there to Hmong Club because we should have pride in being Hmong." Students also viewed the Club as an avenue for the recognition of the Hmong as a distinct Asian ethnic group. Pakou, the Hmong Club secretary, shared that the Club was important for "explaining to people when they ask, 'What is Hmong?' 'cause a lot of people, they tend to not know Hmong." Chris Vang echoed this sentiment:

I just wanted to expand, expand the fame of Hmong. 'Cause you look around the United States. Hmong is not really known. Only [this state] know Hmong people. In other places in the states they don't know about Hmong people. They know Japanese. They call you like, "Are you Chinese? Are you Japanese?" . . . But then, it's kinda like a stereotype. I just really want to make Hmong people act more, be acknowledged.

Hmong students like Pakou and Chris Vang viewed the Hmong Club as a means to educate the broader public about Hmong Americans. As the students pointed out, while the mainstream public knows about Asian American groups such as Chinese and Japanese ethnics, there is a lack of knowledge about Hmong immigrants in the U.S. (cf., Ngo, 2010).

As Hmong students embraced a "one true culture" (Hall, 1990) of Hmong culture and identity, they also took up the ideologies of multiculturalism and ethnic authenticity of the school and broader Hmong community. Problematically, as an idealized discourse that attempts to invent or create affinity, liberal multiculturalism contradictorily reinforced culture as a static entity and cultural difference as "exotic" and "Other" (Britzman, 1998; Mohanty, 1994). Nevertheless, I suggest Hmong Club was a site of place-making where students could amplify their sense of cultural identity and carve out belonging in the spaces of school. While the Club was intended to help educate Hmong and non-Hmong students about Hmong culture, very rarely did the Club meetings focus on Hmong history, language or traditions. By and large, Hmong students often engaged in social activities as they constructed a "home" (Hall, 1995) for themselves. With few exceptions (e.g., Multicultural Festival preparation) students played games like Mafia/Werewolf or Motorcycle; watched Korean or Thai movies together; and coordinated events like a Halloween party and Secret Santa gift exchange.

Toward the end of the year, I talked to Mr. Moua, one of the Club's co-advisors, about this observation. His response underscored the need to create a positive space for Hmong culture and identity:

But I guess, it's a group and a social group and a gathering of people who want to do things that are positive and have the Hmong name to it. We can support this thing and it's the Hmong Club. That's helping. So then, it's keeping the image of the Hmong students here in a good name, I suppose. And it's also, I think an avenue for them to feel positive about their culture and where they come from (emphasis added)

The Hmong Culture Club at Dayton High did not unequivocally reproduce the Hmong community or liberal multiculturalism's discourse of cultural authenticity. It served more as a symbolic function that discursively strengthened Hmong cultural identity within the school by "keeping the image of the Hmong students in a good name." As acknowledged by Mr. Moua, the Club was a social group that provided students with a way to be positive about their cultural background and identity. 
Nhia, the Hmong Club Vice President, also noted the presence of negative views about Hmong culture:

Well, Hmong Club would be more like, we like our traditional more. We like our culture. And as for me, I think like the Hmong Club all have said that I'm more into my culture . . . . Like I'm proud of being Hmong and I get a lot of bad comments from other people for being vice-president, but I don't really care . . . . 'cause I'm Hmong so I just wanna be, show who, I just want to show that I'm Hmong and that I'm not ashamed to admit that I'm Hmong . . . . Hmong students don't know how to speak the Hmong language, and they're like, "Yeah, Hmong people are so ghetto and blah blah blah. But I'm like, "Nah, you can change your thought and you can always change your way, but you can never change the color of your hair."

In a school where almost half of the students are Asian American, and the majority of whom are Hmong, Nhia suggested that the students in Hmong Club are the ones who "like" Hmong Culture. Her comment about Hmong students not knowing the language and disparaging other Hmong people as "so ghetto" points to the negative perception of what it means to be Hmong. As a student, Nhia saw this, but chose to be part of Hmong Club because she was "not ashamed to admit that [she's] Hmong."

Ms. Khang, the co-advisor, particularly stressed the importance of the word "Hmong" for the students in the Club. She suggested that Hmong Club was a symbolic site for Hmong American students at Dayton:

It's the identity. It's the feeling of using the word Hmong. It's the purpose of saying, "We're Hmong. We're not this other Southeast Asian." 'Cause the other Southeast Asian group, they have, they can point to themselves in a map or globe or something . . And the funny thing too is that most of the SEA kids [Southeast Asian Club at the school] are Hmong . . . . The Hmong Club, the kids who want to be in Hmong Club, want to identify who they are. And, the word "Hmong Club" it's a security-ness (emphasis added).

According to Ms. Khang, while other Southeast Asian groups have geographic locations identifiable on a map or globe, Hmong students do not have a country of their own. Students wanted a student group with "Hmong" in its name because it provided them with "a securityness."

After Blia reviewed the agenda for the meeting she asked for additions to the agenda. As he leaned against the frame of the door, Mr. Moua raised his hand and announced that he would like to add a discussion of the merger of the Hmong Club and Southeast Asian Club to the agenda. Students immediately started whispering in hushed tones. Mr. Moua briefly explained that Ms. Tanner, the advisor of the SEA Club, wanted to combine the two clubs because the students are "the same" for both clubs-they are all Hmong students. This announcement caused commotion in the room as students expressed their opinions more loudly to each other. From the center front of the room, Tom Lor, put his right fist in the air and cried out, "United Asians!" On my left, Nhia informed Mai that the Southeast Asian Club is "not welcoming." Mr. Moua interrupted the impromptu 
Ngo - Hmong Culture Club as a Place of Belonging

discussion by telling the students, "For now, the item should just be put on the agenda. We can hold the discussion later."

$* * * *$

The meeting then turned to the merger of the Hmong Club with the Southeast Asian Club. Mr. Moua explained again that Ms. Tanner came to him and asked if students from the Hmong Club would like to combine their Club with the Southeast Asian Club, since Hmong students make up both clubs. He explained that the clubs have existed based on the ideas that the Hmong Club is "more focused on culture" and the Southeast Asian Club more focused on students and experiences of the Southeast Asian region. Mr. Moua then asked students for their input. Nhia was the first student to make a comment. She shared with the group that she doesn't want the clubs to combine because she worries that if they merge, the students in the Hmong Club may not be able to follow their own rules, and may have to follow the rules of the Southeast Asian Club. Tom Lor, always the comic relief, announced, "We'll make them follow our rules!" Nhia continued to say that the Hmong Club's focus on Hmong culture is good, and that it is important to have that freedom. (FN, 11/8/06, Hmong Club)

At the end of the discussion about a merger of the clubs, Mr. Moua asked for a raise of hand for whether or not the Hmong Club should merge with the Southeast Asian Club. The students voted unanimously to not merge. Despite the fact that the clubs were comprised of Hmong members, the Hmong Club students did not want to be part of the pan-ethnic (Espiritu, 1992) "Southeast Asian Club." The Hmong Club members wanted a place specifically with "Hmong" in its name because they wanted a place in the world. Hmong Club gave students a cultural location where they were able to claim "they belong to a particular place to which other groups do not belong" (Rose, 1995, p. 99).

Perhaps more than anything, Club meetings served as a space where the members could be in the same room together. Consider the words of Long, one of the members:

I went to Hmong Club because like I thought I was losing my culture. Because my sister says that the fastest way to lose your own culture is through language. So I was thinking about it and it seemed kind of true, right? So I thought that Hmong Club was going to be surrounded with Hmong. And they do. So I don't feel bad about losing my culture. So, they do kind of keep me in touch with my culture. And that's what I like about it .... It just seems like, it just keeps my culture. I just know that it keeps my culture kind of safe (my emphasis).

Echoing the fears of Hmong community leaders, students like Long were concerned about losing his culture. Similar to Ms. Khang, who suggested the focus on "Hmong" provided students with "security-ness," Long believed that the Club was able to keep his culture and identity "safe."

Notably, he saw that because "Hmong Club was going to be surrounded with Hmong" it would help to "keep [him] in touch with [his] culture." The shared social community-Hmong Club as place - contributed to a sense of cultural identity and belonging (Rose, 1995).

Although the Hmong Club invoked an historical past of Hmong culture and identity, Hmong Club advisors and members were actually in the "process of becoming" (Hall, 1996, p. 4). Below, I show the ways in which Hmong youth were in the process of "becoming" (Hall, 1996) engaged citizens. 


\section{Nurturing Civic Identities}

During the spring of 2006 the Harriet City Public Schools hired a new superintendent, Deborah Finch, a Harvard graduate and top official from the Washington, D.C. public schools. By October 2006, Hmong community leaders were wary because of the superintendent's negative stance toward English Language Learners (ELL) and her snobby "East Coast" attitude. Their concerns were exacerbated by the knowledge that Shoua Her, the only senior staff member at the district office, was leaving the district in early 2007 to open a Hmong charter school. At the end of October Hmong community leaders organized a Hmong community forum with the superintendent to highlight their concerns about the education of Hmong students in the district. One primary aim of the community meeting was to show the superintendent that she needed to respond to the needs of Hmong families through a show of "the numbers" or "force" of the Hmong community.

Echoing the concerns of the wider community about the lack of attention to Hmong students and families, the Hmong Club became a site of mobilization to help with the community forum with Superintendent Finch. The Club advisors introduced the issue to the Hmong community, and invited them to take part in the meeting:

Ms. Khang speaks for fifteen minutes about the Hmong community meeting with Superintendent Finch. "This is a very important meeting," she says, and tells students it's important to know the Superintendent's name, because she is in charge of all the schools in Harriet City and is the "face of Harriet City Public Schools." Ms. Khang shares that she was appointed to organize the food and decorations for the meeting and that she would like the Hmong Club to assist her. She'd like "Dayton High School's Hmong Club" to come at 3:00 to Martin High School to help Shoua Her and Dia Lee [Hmong community leaders] with the event. This work will involve decorating, moving tables, setting out the food. Students will also help out as ushers . . . . Ms. Khang tells the students that she wants the Superintendent to know that "our" community is "a big community," and that it will be important to show her that the Hmong community is "professional," "organized," and that "education is important." The Hmong Club, Ms. Khang said, will be her "right and left arms" at the meeting. . . . Mr. Moua stresses again to the Club members that the meeting is an important opportunity for the Hmong community. It is "the time to tell the Superintendent what we want." He then asks the students to volunteer to help Ms. Khang, and passes out a sign-up sheet. (FN 10/25/06, Hmong Club)

As members of the Hmong Club, students learned about and engaged in the concerns and activities of the community. They volunteered to help with the Hmong community forum and "tell the Superintendent what we want." Approximately half of the twenty students in attendance signed up, and worked out carpools to the meeting.

Two months later, Superintendent Finch appointed seven district administrators to the top leadership team that directly reported to her on a regular basis. Noticeably absent was a Hmong American on her senior staff to make up for Shoua Her's departure from the school district. The announcement of the leadership team coincided with the day of the Hmong Club meeting in late December. At the meeting, Mr. Moua asked Club members to read two articles from the city 
paper, one announcing the new district leadership team and the other the departure of Shoua Her from Harriet City Public Schools. Mr. Moua then engaged students in a conversation about the implications for their education:

MR. MOUA: Do you know how many Hmong students are in the district? That's right, a little over $30 \%$. What do you think that will mean with the only Hmong person gone?

YENG: No one will hear the Hmong voice.

MR. MOUA: What do you think of the Superintendent's restructuring? Do you see any Hmong people listed? Why is that a problem?

TOM LOR: Because there's no one to represent us.

Mr. Moua then gives an example of a situation where all white people are making the decisions. Then asks, "Do you think they understand us?

STUDENTS: No

YENG: Because they don't know our culture.

Mr. Moua gives another example where there's a Hmong person is a representative and asks if the students see how that's "more fair."

MR. MOUA: What I want you to understand is that no one in the district understands our culture. Your voice and your parents' voice are very important. Parents have a bigger voice. Parents have to be active. You need to go talk to your parents. If you don't have someone to represent you, that's bad. You are in Hmong Club. You are saying you care about Hmong culture. Does it make sense that a district with 30\% Hmong has no one down in the district? We have no voice. We don't have representation anymore.

TOM LOR: Someone has to step up.

MR. MOUA: That's right.

KABLIA: Why is she leaving?

MR. MOUA: She's leaving to start the new school.

TOM LOR: The question is, who is qualified?

MR. MOUA: There are lots of qualified Hmong people. People who have $\mathrm{PhDs}$, people who are principals and assistant principals.

TOM LOR: Are you qualified?

MR. MOUA: No, I'm not qualified.

TOM LOR: How about Mr. Lee?

MR. MOUA: Yes, we can talk to Mr. Lee.

COLLEGE STUDENT: This issue is the same as mine. We need to let leaders know that you have power and they need to listen. You guys are the voice of the Hmong community.

As the end of the Club's meeting time approached, Tom Lor asked, "Is it possible to bring up the issue again?" because he wanted to discuss the issue further during other Hmong Club meetings. He then asked Mr. Moua if they could contact the other schools in the district. Mr. Moua said "Yes. That's a good idea." Together with other students, Mr. Moua listed the names of the other high schools on the board.

As Hmong Club engaged with the cultural politics of ethnic representation in the district office, Hmong students were introduced to discourses of democratic change (Evans \& Boyte, 1986). Club advisor Mr. Moua wanted Hmong students to think about social issues and responsibility: "I want them to work on issues that contribute back to the community, which is a 
Ngo: Hmong Culture Club as a Place of Belonging

Ngo - Hmong Culture Club as a Place of Belonging

Dayton community, but also realize that there are other bigger issues outside. How does that bigger issue impact you here and how you perceive the world?" Hmong Club was a site that highlighted, reflected and involved Hmong students in the politics and concerns of the broader community.

In the weeks that followed, similar discussions occurred in Harriet City's Hmong community. Stories about the dispute between the Hmong community and superintendent appeared in the city paper and Hmong community papers. Hmong policymakers met individually with Superintendent Finch; and Hmong organizations, parents, and students organized a petition that requested an appointment of a Hmong staff to the leadership team, an increase in Hmong staff at all levels of the district, and a range of changes to improve school climate, curriculum and instruction for Hmong students. Although Superintendent Finch did not acquiesce to the demands of the Hmong community, she promoted a Hmong district staff member to a senior staff position.

\section{Conclusion}

At Dayton High School, Hmong Culture Club served the symbolic purpose of narrating a "place" in the world for Hmong students. The students' discursive emphasis on a collective "one true self" (Hall, 1990) of Hmong culture provided them with a means to carve out a sense of belonging in the world. Even as Hmong students discursively took up multicultural ideologies of a "closed" culture and the Hmong community's avowal of a "return" to cultural origins, they did not fully embrace the ideals. Rather than a place where students immersed themselves in learning about the history, traditions and language of the Hmong community, Hmong Club was meaningful to students as a place of belonging that affirmed their identities as Hmong Americans.

It is worth repeating that for minoritized groups, the emphasis on the "loss" of culture or the need to "return' to one's cultural roots, [as a way] to hold fast to one's founding identity; and thus "close up the community around its foundational cultural beliefs and values" (Hall, 1995 , p. 200, italics in original) must be viewed as a response to power relations rather than a simple attachment to originary ideals about culture (Gilroy, 1994; Hall, 1995; Massey \& Jess, 1995). Cultural survival for many groups has often manifested in what Hall (1995) calls the "strategy" of "the revival of ethnicity" (p. 200) and its attempts to keep culture unified, homogenous and intact.

In the context of U.S. cultural politics (Maira, 2008), the yearning of immigrants for "tradition" needs to be situated within the nation's extensive history of anti-immigrant discourses, policies and practices (e.g., Jaret, 1999); and school deficit policies and practices that ignore the cultures, histories, and knowledges of immigrant families and divest students of their language and culture (Gonzalez, Moll, \& Amanti, 2005; Valenzuela, 1999). As this article illustrated, Hmong leaders Kou Vang and Pachee Vue see students struggling to belong, amidst discourses that tell them that they do not "fit in" and practices that exclude the ethnic history of the Hmong in curriculum and instruction. Likewise, students in Hmong Club recognize the lack of knowledge about the Hmong community as well as negative perceptions about what it means to be Hmong.

Against the backdrop of policies and practices that denigrated the identities of Hmong Americans, Hmong Culture Club provided students with a space that affirmed Hmong culture 
and identity. Speaking of the "homeplace" of African American families as sites of humanization and resistance, hooks (1990) stress the importance of such places of (racial/ethnic) belonging:

The task of making homeplace ... was about the construction of a safe place where black people could affirm one another and by so doing heal many of the wounds inflicted by racist domination. We could not learn to love or respect ourselves in the culture of white supremacy, on the outside; it was there on the inside, in that "homeplace" that we had the opportunity to grow and develop, to nurture our spirits (42).

For hooks, the healing of wounds and nurturing of spirits took place at kitchen tables and constructed out of conversations and laughter. In similar ways, the Hmong Club students transformed "space" into "place" and established a "sense of belongingness" (Hall, 1995) in social activities that was primarily about being together in the same space. Their political selfrecovery was further enhanced by engagement with the superintendent's controversy about the lack of a Hmong staff on the school district leadership team.

Even as Hmong Club students took up liberal multiculturalism's focus on an essentialized, "one true" culture (Hall, 1990), the Club served a different purpose-one of positive identity-making that cultivated the cultural and political identities of the Hmong American students. As a "youthscape" (Maira \& Soep, 2005) for immigrant youth, school cocurricular ethnic student clubs are learning environments that grapple with the complexity of youth identities in the global era. This study provides directions for future research on the spaces of extracurricular "culture clubs" that are grounded in ideologies of multiculturalism. Further research is needed that examines questions such as: (1) How do school culture clubs provide minoritized students with a space to cultivate cultural and political identities? And (2) How do school culture clubs complicate or reinforce notions of culture?

\section{Endnotes}

\footnotetext{
${ }^{\mathrm{i}}$ The names of people and places in this article are pseudonyms.

ii This percentage is based on district home language data.

iii The multiple methods and multiple data sources of an ethnographic design and analysis procedures provided triangulation for the study. For example, interviews provided opportunities to confirm and follow-up on fieldwork observations. Although I attempted to conduct member checks of interview transcripts, student and adult participant either told me it was unnecessary or did not respond to e-mails asking them to check interview transcripts.

${ }^{\text {iv }}$ At the time of the study, there were approximately half a dozen Hmong charter schools and half a dozen Hmong non-profit organizations in the area.

${ }^{\mathrm{v}}$ Given the small number of Hmong Americans in leadership positions, I am withholding details about the individuals and positions in order to safeguard privacy and confidentiality.

${ }^{v i}$ See Ngo (2013) for similar perspectives from other Hmong American community leaders in the study.
} 


\section{References}

Anderson, K., Demosh, M., Thrift, N. \& Pile, S. (2002). Handbook of cultural geography. Thousand Oaks, CA: Sage Publications.

Britzman, D. P. (1995). “The question of belief": Writing poststructural ethnography. Qualitative Studies in Education, 8(3), 229-238.

Denzin, N. \& Lincoln, Y. (Eds.) (2000). The handbook of qualitative research, $3^{\text {rd }}$ edition. Thousand Oaks, CA: Sage Publications.

Emerson, R.M., Fretz, R. I., \& Shaw, L. L. (1998). Writing Ethnographic Fieldnotes. Chicago, IL: University of Chicago Press.

Entrikin, J. N. (1991). The betweenness of place. Cambridge, UK: Polity Press.

Espiritu, Y. L. (1992). Asian American panethnicity. Philadelphia, PA: Temple University Press.

Evans, S. \& Boyte, H. (1986). Free spaces: The sources of democratic change in America. Chicago, IL: University of Chicago Press.

Feagans, B. 2006. Generation 1.5: Young immigrants in two worlds. The Atlanta JournalConstitution, September 3, Retrieved November 15, 2006 from http://www.proquest.umi.com.

Fetterman, D. (1998). Ethnography: Step-by-step, $2^{\text {nd }}$ edition. Thousand Oaks, CA: Sage Publications.

Fine, M. (1994). Working the hyphens: Reinventing the Self and Other in qualitative research. In N.R. Denzin \& Y.S. Lincoln (Eds.), Handbook of Qualitative Research, 70-82. Thousand Oaks, CA: Sage.

Fish, S. (1997). Boutique multiculturalism, or why liberals are incapable of thinking about hate speech. Critical inquiry, 378-395.

Gilroy, P. (1994). The Black Atlantic. London, UK: Verso.

González, N., Moll, L., \& Amanti, C. (2005). Funds of Knowledge. Mahwah, NJ: Lawrence Erlbaum.

Hall, S. (1990). Cultural identity and diaspora. In J. Rutherford (Ed.), Identity: Community, culture, difference (pp. 222-239). London, UK: Lawrence and Wishart.

Hall, S. (1995). New cultures for old. In D. Massey \& P. Jess (Eds) A place in the world? (pp. 175-213). Oxford, UK: Oxford University Press.

Hall, S. (1996). Introduction: Who needs identity? In S. Hall \& P. Du Gay, (Eds.), Questions of cultural identity, (pp. 1-17). London, UK: Sage.

hooks, b. (1990). Yearning: Race, gender and cultural politics. Boston, MA: South End Press.

Jaret, C. (1999). Troubled by newcomers: Anti-immigrant attitudes and action during two eras of mass immigration to the United States. Journal of American Ethnic History, 18(3), 9-39.

Lee, S. J. (2005). Up against whiteness: Race, schools, and immigrant students. New York, NY: Teachers College Press.

Louwagie, P., \& Browning, D. (2005, October 9). Shamed into silence. Star Tribune. Retrieved November 15, 2006, from http://www.proquest.umi.com

Low, S. M., \& Lawrence-Zuniga, D. (2003). The anthropology of space and place: Locating culture. Malden, MA: Blackwell Publishing.

Lugones, M., \& Price, J. (1995). Dominant culture: el deseo por un alma pobre (the desire for an impoverished soul), in D A Harris (Ed.), Multiculturalism from the Margins: Nondominant Voices on Difference and Diversity, (pp 103-127). Westport, CT: Bergin and Garvey. 
Ngo - Hmong Culture Club as a Place of Belonging

Maira, S. (2002). Desis in the house: Indian American youth culture in NYC. Philadelphia, PA: Temple University Press.

Maira, S. (2008). Flexible citizenship/Flexible empire: South Asian Muslim youth in Post-9/11 America. American Quarterly, 60(3), 697-720.

Maira, S., \& Soep, E. (Eds.) (2005). Youthscapes: The popular, the national, the global. Philadelphia, PA: University of Pennsylvania Press.

Massey, D. (1994). Space, place and gender. Cambridge, UK: Polity Press.

Massey, D., \& Jess, P. (1995). Places and cultures in an uneven world. In D. Massey \& P. Jess (Eds.), A place in the world? (pp. 216-238). Oxford, UK: Oxford University Press.

Mohanty, C.T. (1994). On race and voice: Challenges for liberal education in the 1990s. In H. Giroux \& P. McLaren (Eds.), Between borders: Pedagogy and the politics of cultural studies (pp. 145-166). New York, NY: Routledge.

Ngo, B. (2008). Beyond "culture clash" understandings of immigrant experiences. Theory into Practice, 47(1), 4-11.

Ngo, B. (2010a). Unresolved identities: Discourse, ambivalence and urban immigrant students. New York, NY: State University of New York Press.

Ngo, B. (2010b). Doing “diversity” at Dynamic High: Problems and possibilities of multicultural education in practice. Education and Urban Society, 42(4), 473-495.

Ngo, B. (2013). Culture consciousness among Hmong immigrant leaders: Beyond the dichotomy of cultural essentialism and cultural hybridity. American Educational Research Journal, $50(5), 958-990$.

Ngo, B., \& Lee, S. (2007). Complicating the image of model minority success: A review of Southeast Asian American education. Review of Educational Research, 77(4), 415-453.

Rose, G. (1995). Place and identity: A sense of place. In D. Massey \& P. Jess (Eds.), A place in the world? (pp. 87-132). Oxford, UK: Oxford University Press.

Strauss, A. \& Corbin, J. (1998). Basics of qualitative research: Grounded theory procedures and techniques, $2^{\text {nd }}$ ed. Newbury Park, CA: Sage.

Suarez-Orozco, M. (1996). California dreaming: Proposition 187 and cultural psychology of racial and ethnic exclusion. Anthropology and Education Quarterly, 27, 151-167.

Thomas, M. E. (2008). The paradoxes of personhood: banal multiculturalism and racial-ethnic identification among Latina and Armenian girls at a Los Angeles high school. Environment and Planning, 40(12), 2864-2878.

Tuan, M. (1998). Forever foreigners or honorary whites? New Burnswick, NJ: Rutgers University Press.

Valenzuela, A. (1999). Subtractive schooling: U.S. Mexican youth and the politics of caring. Albany, NY: State University of New York Press.

West, T.R. (2002). Signs of struggle: The rhetorical politics of cultural difference. New York, NY: SUNY Press.

Yon, D. (2000). Elusive culture: Schooling, race and identity in global times. New York, NY: State University of New York Press.

Zhou, M. \& Kim, S. (2006). Community forces, social capital, and educational achievement: The case of supplementary education in the Chinese and Korean immigrant communities. Harvard Educational Review, $\quad$ 76(1), 


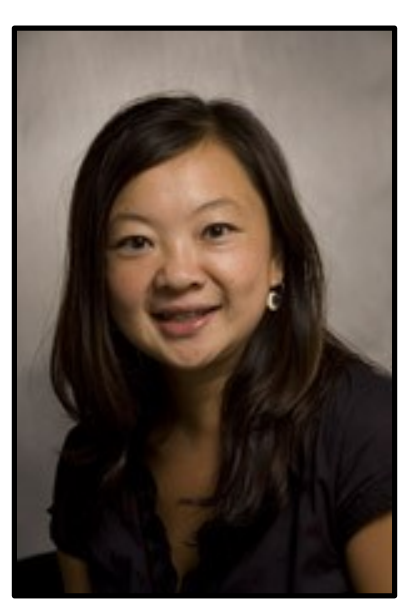

Bic Ngo is an Associate Professor of Culture and Teaching in the Department of Curriculum and Instruction at the University of Minnesota. She examines "culture" and "difference" in the education of immigrant students, and the implications for theorizing immigrant identity, culturally relevant pedagogy, and anti-oppressive education. Her research has focused primarily on Lao American and Hmong American educational experiences. This research has included extensive engagement with the Hmong American community in the Twin Cities area, including Hmong American high school students, college students, LGBT youth, and Wat Tham Krabok Hmong refugee parents. She is a recipient of the Scholars Award from the William T. Grant Foundation and the Early Career Award from the Committee on Scholars of Color in Education, American Education Research Association. Her books include Unresolved Identities: Discourse, Ambivalence and Urban Immigrant Youth (SUNY), Six Lenses for Anti-Oppressive Education (Peter Lang). Her articles have appeared in outlets such as the American Education Research Journal and Anthropology and Education Quarterly. 


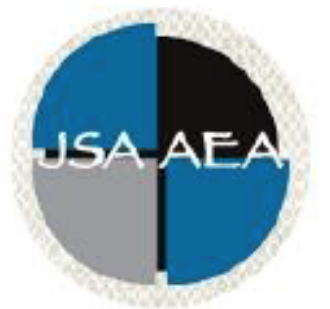

Vol. 10 Iss. 2 Special Issue (2015)

\section{Journal of Southeast Asian American Education and Advancement}

www.JSAAEA.org

\section{Special Issue Editors}

Vichet Chhuon

University of Minnesota

anthony lising antonio

Stanford University

\section{Editor}

Dr. Wayne E. Wright

Purdue University

\begin{abstract}
Associate Editors
Dr. Chhany Sak-Humphry

University of Hawaii at Manoa
\end{abstract}

Dr. Phitsamay Sychitkokhong Uy

University of Massachusetts, Lowell

\section{Book Review Editor}

Dr. Vichet Chhuon

University of Minnesota

\section{Creative Works Editor \\ Bryan Thao Worra \\ Lao Assistance Center}

\section{Journal Manager \\ Marshall Klassen \\ Purdue University}

\section{Editorial Review Board}

Dr. Steve Arounsack

California State University, Stanislaus

Dr. Sovicheth Boun

The State University of New York at Fredonia

Dr. George Chigas

University of Massachusetts, Lowell

Dr. Hien Duc Do

San Jose State University

Dr. Sophal Ear

Occidental College
Dr. Carl L. Bankston III

Tulane University

Dr. Phala Chea

Lowell Public Schools

Dr. Loan Dao

University of Massachusetts, Boston

Dr. Changming Duan

University of Missouri, Kansas City

Dr. Sothy Eng

Lehigh University 
Dr. Jeremy Hein

University of Wisconsin, Eau Claire

Dr. Nancy H. Hornberger

University of Pennsylvania

Dr. Peter Nien-Chu Kiang

University of Massachusetts, Boston

Dr. Ha Lam

Arizona State University

Dr. Jonathan H. X. Lee

San Francisco State University

Dr. Monirith Ly

Royal University of Phnom Penh

Dr. Bic Ngo

University of Minnesota

Dr. Leakhena Nou

California State University, Long Beach

Dr. Mark Pfeifer

SUNY Institute of Technology

Dr. Loan T. Phan

University of New Hampshire

Dr. Kalyani Rai

University of Wisconsin, Milwaukee

Dr. Cathy J. Schlund-Vials

University of Connecticut, Storrs

Dr. Nancy J. Smith-Hefner

Boston University

Dr. Yer J. Thao

Portland State University

Dr. Monica M. Trieu

Purdue University

Dr. Silvy Un

Saint Paul Public Schools

Dr. Terrence G. Wiley

Center for Applied Linguistics

\author{
Dr. Vincent K. Her \\ University of Wisconsin, Eau Claire \\ Dr. Peter Tan Keo \\ New York University \\ Dr. Kevin K. Kumashiro \\ University of San Francisco \\ Dr. Ravy Lao \\ California State University, Los Angeles \\ Dr. Stacey Lee \\ University of Wisconsin, Madison \\ Dr. Sue Needham \\ California State University, Dominguez Hills \\ Dr. Max Niedzwiecki \\ Daylight Consulting Group \\ Dr. Clara Park \\ California State University, Northridge \\ Dr. Giang Pham \\ University of Massachusetts \\ Dr. Karen Quintiliani \\ California State University, Long Beach \\ Dr. Angela Reyes \\ Hunter College, The City University of New York \\ Dr. Fay Shin \\ California State University, Long Beach \\ Dr. Christine Su \\ Ohio University \\ Dr. Alisia Tran \\ Arizona State University \\ Dr. Khatharya Um \\ University of California, Berkeley \\ Dr. Linda Trinh Vo \\ University of California, Irvine \\ Dr. Yang Sao Xiong \\ University of Wisconsin-Madison
}

Dr. Zha Blong Xiong

University of Minnesota

\section{Doctoral Student Editorial Review Board}

\author{
Virak Chan \\ University of Texas at San Antonio \\ Annie BichLoan Duong \\ San Joaquin County Office of Education \\ Hoa Nha Nguyen \\ Boston College \\ Malaphone Phommasa \\ University of California, Santa Barbara
}

\author{
Keo Chea-Young \\ University of Pennsylvania \\ Dung Minh Mao \\ University of Minnesota \\ Thien-Huong Ninh \\ University of Southern California \\ Krissyvan Truong \\ Claremont Graduate University
}


Journal of Southeast Asian American Education and Advancement, Vol. 10 [2015], Iss. 2, Art. 2

Molly Wiebie

The University of Texas at Austin

\section{Soua Xiong}

San Diego State University \&

Claremont Graduate University

Anna H. Yang

University of Georgia

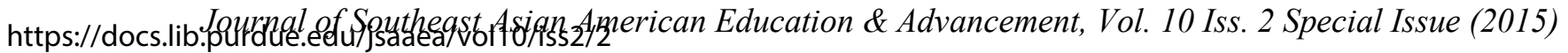

